\title{
The Effectiveness and Efficiency of Cadets (Student) Care Patterns Implementation of Character Education in Polytechnic Flight Jayapura
}

\author{
Jemi V. Palpialy ${ }^{1}$, Akilla Makanuay ${ }^{2}$ \\ ${ }^{1,2}$ Program Study Electrical Engineering Airport, Polytechnics Flight Jayapura, Indonesia
}

Corresponding Author: Jemi V. Palpialy

\begin{abstract}
Nowadays, multidimensional crises are increasingly reaching down to the smallest social sphere, rooting in the decreasing quality of the nation's character. Character education is one solution to overcome these problems. In this study, it discusses the Jayapura Aviation Polytechnic as a formal institution that is expected to carry out character education for its cadets so that they are able, create and cultivate the nation's successors with good character according to the values adopted.
\end{abstract}

Keywords: Character education, cadets, Jayapura Aviation Polytechnic

\section{INTRODUCTION}

The flow of globalization has had a wide impact in various parts of the world, both positive and negative impacts. The negative impact is violence, drug abuse, free sex, and crime. All these things lead to a loss of national character. Thus, character education is present as one of the filters for the negative effects of globalization. Hurlock (2013) argues that adolescence is a period of stormy winds, tidal storms, and uncertain ebbs, such as firecrackers whose axes can fire automatically and can explode at any time.

The development of psychology in adolescents is very significant. His critical character began to develop and did not want to immediately comply with suggestions or prohibitions directed at him. Character education is interpreted as a systematic and planned effort to cultivate, develop or inculcate noble qualities in the soul so that from these noble traits, noble behavior is born that has become a necessity of life. Personality with character is needed by a person in pursuing his life, both in a social environment or a work career, as well as in social life. The success of character education is influenced by the collaboration and synergy with various kinds of communities that have the potential to develop individual character formation in educational institutions. In connection with the description above, to be effective and efficient in the parenting patterns of cadets at the Jayapura Poltekbang, character building in the campus environment is a must.

Based on the background of the above research problems that have been described, then the formulation of the problem in this study is How is the pattern of implementation of character education at Jayapura Aviation Polytechnic and what are the obstacles faced in the implementation of character education at Jayapura Aviation Polytechnic so that any efforts are obtained. carried out in overcoming obstacles in the implementation of character education at Jayapura Aviation Polytechnic

\section{LITERATURE REVIEW}

\subsection{Personality Formation}

The word personality comes from the word Personality (in English) which comes from the word Persona (Latin) which 
means mask or mask. The point is the face cover which is often used by stage performers which aims to describe a person's behavior, character, or personality. Gordon W. Allport in his literature study found nearly 50 definitions of different personalities. He then found a formula that was considered a more complete definition of personality.

This definition is that personality is a dynamic organization within the individual as a psycho-physical system that determines his unique way of adapting to his environment. The keyword in understanding personality is an adjustment. Schneider defines self-adjustment as "a process of individual response both behavioral and mental to overcome internal needs, emotional tension, frustration, and conflict, and maintain a balance between meeting these needs and the demands (norms) of the environment. Different personality development experts have different views.

The following are among some experts regarding the development of personality from a sociological perspective:

\section{1) Charles Horton Cooley: Mirror Self} (looking Glass Self)

The concept of looking-glass self (selfmirror) describes an analogy to selfdevelopment through a mirror. This concept has 3 elements, namely:

a) Envision yourself as it appears to others. For example, we may think that other people perceive us as friendly or angry.

b) Interpreting other people's reactions. We try to conclude other people's reactions. Do they like us as friendly people?

c) Developing a self-concept (selfconcept). How to interpret the reactions of others to yourself will give feelings and ideas about yourself. This pleasant reflection in the mirror of the social self will lead to a positive self-concept and if it is a negative reflection it will lead to a negative self-concept. This self-concept according to Cooley will occur throughout life, because it is a product that is never finished being formed even until old age.

\section{2) Mead: Stages of Self Development}

Mead argues that the stage of human self-development takes place through the preparatory stage or the play stage, the game stage, and the generalized stage. At the preparatory stage, a child will learn to take the perspective of others which he considers according to his life's needs, and see himself as an object. In the next stage, namely the match, a child not only knows the role he plays but also knows the roles of other people with whom he interacts. Whereas in the final stage, namely the generalized other, a child can control his behavior according to a general role that is impersonal. Children are also able to know how to behave and behave, for example how to say words according to the person being faced.

\section{3) Sigmund Freud: The Three Elements of the Self}

Freud explained 3 elements in humans, namely the Id, superego, and ego. The id is the center of lust and drives which is instinctive and asocial, greedy and antisocial. The superego is an element of the self that is social and forms conscience. Meanwhile, ego means the self-conscious and rational element. This element is a balance between the innate impulses and the demands of society.

\subsection{Character building}

Etymologically, the word character means character, psychological traits, character, or character that distinguishes a person from another, or character.

In English terms, character corresponds to "character" which means "All the mental and moral qualities that make a person, groups of people, and places different from others. from the other). According to Samsuri, the word character contains at least 2 things, namely values and personality. A character is a reflection of what values are inherent in an entity, while the aspects of personality, character are a reflection of the whole personality of a person: mentality, attitudes, and behavior. A 
person who has character means he has morals and manners. There are four types of character that have been known and implemented in the education process, namely character education based on religious values which is the truth of God's revelation (moral conservation), character education based on cultural values, environment-based character education (environmental conservation), and potentialbased character education self. Based on the description and scheme above, it is necessary to combine the theory of characteristics so that the position and implementation of character education for cadets are known. Resocialization is a type of socialization that is divided based on needs. This socialization is also known as secondary socialization. Resocialization means re-socialization, which is a process of learning new norms, values, attitudes, and behaviors to match the new situations they face. Resocialization can occur in the form of anticipatory socialization, namely socialization that occurs for people who will play a new role. For example, someone who did an internship before actually serving a position or such as the orientation period for new students in college.

\section{METHOD}

Research Method is a scientific activity that aims to find the truth (Rachman, 1992: 2). Finding the truth through research activities can be done by two methods, namely qualitative research and quantitative research.

The basis of this research is qualitative research that produces descriptive data in the form of written or spoken words from people and observable behavior (Bogdan and Taylor in Moleong, 2004: 2). Researchers conducted research on the implementation of character education at the Jayapura Aviation Polytechnic.

\subsection{Data Analysis Method}

The data analysis method is the process of detailing formal attempts to determine themes and formulating hypotheses or ideas as suggested by the data and as an attempt to assist with those themes and hypotheses (Moleong, 2004: 3).

This study aims to determine the pattern of implementation of character education so that functional interactive analysis is used, which originates from four activities, namely: data collection, data reduction, data presentation, and data verification. The stages carried out by the researcher are:

1. Data collection is defined as a process of data collection activities through interviews and documentation to obtain complete data.

2. Data reduction can be defined as the process of selecting, focusing on simplifying, abstracting, and transforming "rough" data that emerge from written records in the field. Data reduction is a form of analysis that sharpens, classifies, directs, and removes unnecessary and organizes data in such a way that the final results can be drawn and verified there (Milles, 1992: 15-16).

3. Data presentation in this study was conducted to examine, organize and classify data to produce descriptive data.

4. Drawing conclusions or verification, conclusions are re-purpose of records in the field or conclusions can be reviewed as arising from data that must be tested for its validity, robustness, and suitability, namely its validity (Milles, 1992: 19).

\subsection{Research Objectives}

1. Object (target audience) Research: Jayapura Aviation Polytechnic Cadets

2. Implementation period: The period of researching Poltekbang Jayapura for 4 months

3. Proposed Fee: PT Internal Fund: The fee proposed to the Academy is $\mathrm{Rp}$. 22,000,000, - (Twenty Two Million Rupiah).

4. Research Location: Jayapura Aviation Polytechnic 
5. Partners involved (describe what their contribution is): Human Resources and Employment at the Jayapura Poltekbang which will play an important role in integrating the formation of this character and Taruna Poltekbang as research objects.

6. Problems found and solutions offered: When the character formation of cadets is intact both in learning activities and in daily life, limitations arise in the socialization and application. It takes time and gradual practice in its realization.

7. Fundamental contribution to the target audience (describes not more than 50 words, emphasize the benefits obtained): The formation of the character of cadets is developed to create cadets with character in actions and thoughts so that the effectiveness and efficiency of parenting in the Jayapura Aviation Polytechnic campus will be created.

8. Output plans in the form of services, systems, products/goods, patents, or other targeted outputs: 1. Reputable Internal Journal, 2. National / International Proceedings

\subsection{Data Validation Methods}

In qualitative research, the validity of the data can be obtained through triangulation, which is a technique of checking the validity of the data by utilizing something other than outside the data for checking purposes or as a comparison of the data (Moleong, 1998: 178). Tringulation with sources can be achieved in the following way.

1. Comparing the observed data with the interview data.

2. Comparing what people do in public with what they do in private.

3. Compare what people are doing about the research situation with what they are doing over time.

4. Comparing the situation and perspective of a person with various opinions and views of people such as ordinary people, people with secondary or high education, or government people.

5. Comparing the results of the interview with the contents of a related document.

This study uses triangulation techniques by comparing various opinions or views of people.

\section{RESULTS}

\subsection{Overview of the Jayapura Aviation Polytechnic}

Established based on Permenhub Number: PM 28 of 2019 concerning the Organization and work procedures of the Jayapura Aviation Polytechnic. The implementation of study programs at the Jayapura Aviation Polytechnic refers to the laws and regulations in the field of higher education, so that ademic coaching is under the Ministry of Research, Technology and Higher Education while technical management, human resources, budget, infrastructure and operational activities are under the ministry of transportation.

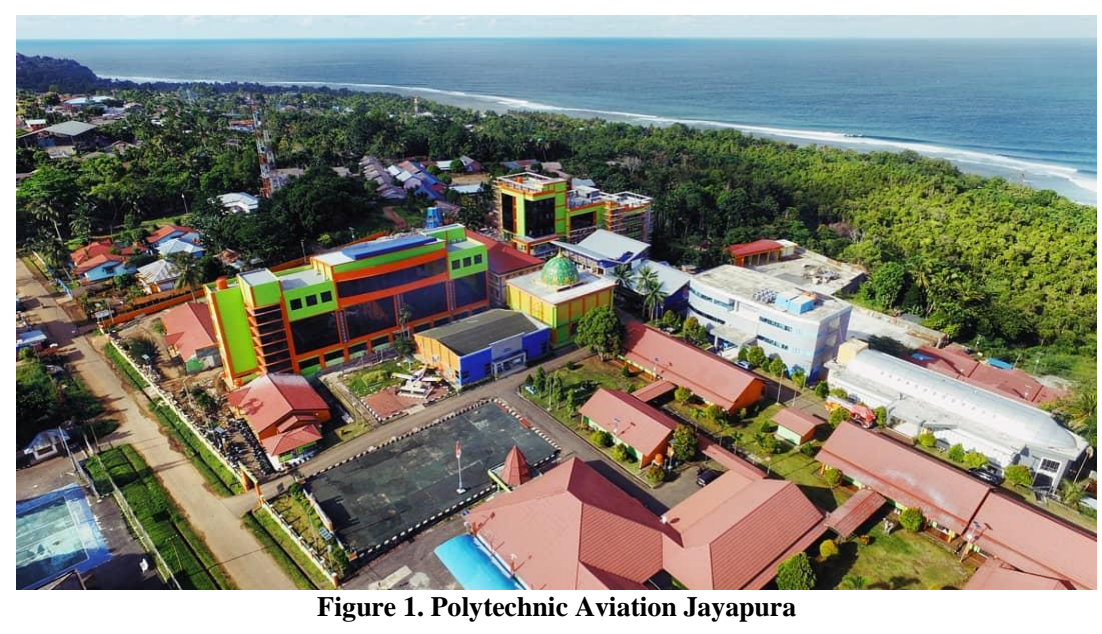


There are 69 cadets at the Jayapura Aviation Polytechnic, who are spread across three study programs, namely airport electricity engineering, air traffic management, airport management and supported by educators who are competent in their fields.

The Tri Dharma carried out by Aviation Polytechnic includes teaching, research and service and is well and maximally managed and directed and implemented with maximum facilities and infrastructure with clean space and complete infrastructure.

\subsection{Cultivating Character Values. 1) Religious}

Religious values are closely related to man's faith in God. Believing can be defined as attitudes and behaviors that show belief in the power of the Creator or God. This belief is accompanied by obedience and obedience in following orders and staying away from His prohibitions. The cultivation of religious values is carried out by the campus through various activities that can get closer to God, so that it will increase the level of faith of students. Activities carried out include the following.

a) Pray before and after the lesson

Based on observations in the youth class, they pray when they will start the lesson. Praying together is an obligation for cadets and has become a series of stages that cadets must do before starting lessons.

b) The campus provides opportunities for cadets to worship according to their respective beliefs.

c) The campus provides facilities that can be used for worship.

d) The campus respects religious holidays

\section{2) Honest}

Honesty is manifested in behavior that does not like lying and cheating. Say what it is and dare to admit mistakes, and are willing to sacrifice for the truth. The campus instills the values of honesty in cadets with activities and the provision of facilities related to honesty. Activities undertaken to in still honesty include the following.

a) Educators objectively assign values to cadets in the learning process

b) Prohibition of carrying communication facilities while in class.

c) No cheating, stealing, cheating. Based on observations in the Academic Office, there is a strict prohibition for cadets to cheat, steal, and cheat as stated in the cadets' code of ethics and honor code. The code of honor must be upheld by cadets. When cadets violate the code of honor there are sanctions for violations

\section{3) Tolerance}

Manifested in attitudes and actions that respect differences in religion, ethnicity, ethnicity, opinions, attitudes and actions of others who are different from themselves. Tolerance is implemented in the following activities.

a) Educators provide equal treatment to all cadets in class regardless of ethnicity, religion, race, class, social status, and economic status.

b) Based on observations made by educators, greeting or returning greetings when meeting with fellow educators, educational staff, or cadets.

c) Get cadets used to work in groups of different religions, ethnicities, tribes and cultures.

d) Respect adherents of other religions to carry out worship. Religious activities together are a form of tolerance cultivation carried out by the campus. Activities carried out in the form of worship at the same time but carried out in different places according to their respective religions.

\section{4) Discipline}

Discipline attitude is manifested by consistent behavior, adhering to the principles towards the goal without the need for continuous supervision and encouragement. Discipline is instilled in cadets through the eyes of activities and 
strict enforcement of rules. Activities carried out by the campus include the following.

a) Scheduled routine activities. Based on the observations made there are scheduled routine activities. Scheduled routine activities are activities that cadets must do every day. These activities consist of various activities from waking up to going back to sleep. Through these activities, cadets are taught to be disciplined.

b) Discipline in the classroom. Based on classroom observations, before the lesson begins the tutor checks the neatness of the cadets, starting from their hair, clothes, to completeness for taking lessons. After that, the report and prayer together, led by the class leader, continued. Then the pamong makes a presence to the cadets and the class leader is obliged to know the cadets who are unable to attend.

c) The existence of campus regulations. Rules are rules made to enforce order and discipline. Enforcement of the rules by imposing fair sanctions for violators of campus discipline. The campus in giving sanctions does not see who the cadets violate but what the violations are, as conveyed by Mr. Edi Kusnadi as Deputy Head of the Campus for Education as follows:

"Always not persuasive towards offenders. Because the rules were made to be implemented. If the rules are not suitable, they may be revised immediately. Do not have rules but those who break the rules are allowed. If it has been much persuasive then be prepared to be violated. So don't be persuasive / permissive towards rule breakers. No favoritism either. Don't look at who broke but what was done".

\section{5) Hard work}

Manifested by a behavior that is always passionate in doing something and does not get tired until the end of the job. Campus instills in cadets the attitude of hard work in the following ways. a) The campus creates an atmosphere of healthy competition. A healthy atmosphere in competition is very necessary to foster an attitude of hard work.

b) The campus creates an atmosphere that is challenging and encourages you to work hard.

c) There is a slogan or motto about active learning. Campus gives enthusiasm to never give up in studying. Based on observations made giving motivation to cadets is given in apples and also in the form of a National Figure Meeting which is held once a year. Invited figures can be sportsmen, businessmen, statesmen, and figures from the military.

d) Programmed activities. Based on observations made, the values of hard work are implanted through activities programmed by the campus. Programmed activities or what are often referred to as extracurricular activities include martial arts, general sports / independent sports.

\section{6) Creative}

Creative is manifested in behavior to solve problems in original ways, be able to see other alternatives, and find new structures with old material. The campus has its own way to bring out the creativity of students, including through various activities as follows.

a) Assignments that challenge the emergence of new works, both authentic and modified.

b) Creating learning situations that can foster thinking and acting creatively.

c) Independent creative activities. Based on the observations made, there are independent creative activities provided by the campus to channel the creativity of cadets.

d) Art Activities. Campus provides opportunities for cadets to show their talents and abilities as well as creativity through various activities related to arts and within organizations. In terms of the arts, the campus holds mandatory events 
which are always held every year, including intimacy nights, English nights, Kartinian, and various competitions.

e) Programmed activities. Based on the observations made, there are programmed activities organized by the campus to develop cadets' creativity, including computers, creativity exhibitions, wall magazines, free time utilization, and marching bands.

\section{7) Independent}

Manifested in behavior that is initiative and consequently responsible for all actions that have been taken. Campus instills independence in cadets in the following ways.

a) Creating a campus life that builds independence for cadets. Campus life that can build independence can be seen from the boarding school system or full boarding campus

b) Independent in managing the personal life of each cadet so that they can manage themselves according to campus life.

\subsection{Character Education Model}

The character education model developed at the Jayapura Aviation Polytechnic is in the form of non-subject activities. Character education in its implementation uses all of daily life as part of the education system implemented so that educational activities at Jayapura Aviation Polytechnic are designed as full boarding schools.

Character education is implemented in everyday life through various activities that have been compiled and included in a special curriculum. Activities organized by the campus to carry out character education, including scheduled routine activities, programmed / extracurricular activities, projected activities, and independent creative activities.

1) Scheduled routine activities are activities that consist of various kinds of activities that must be carried out by cadets every day, namely as follows.
a. 4:45 am wake up in the morning
b. 05.00 worship
c. 5:15 am morning exercise
d. $6: 15$ a.m. breakfast
e. 07.00-13.45 study / kbm
f. 14.00 lunch
g. 15.00-16.00 programmed
h. 18.30 dinner
i. 19.00-21.00 evening study
j. 22.00 rest night

According to the academic and ketarunaan section, scheduled routine activities are activities to develop students' self. In the eyes of self-development activities, cadets are taught something that is basic, including being taught what to do after waking up, what to do when they want to do activities such as learning, sports, including socializing with fellow cadets, cadets with tutors, how to talk good and right, and also how to respect parents / elders. Character education at Jayapura Aviation Polytechnic is not a subject but an application that must be done. Character education is implemented directly in the daily activities of cadets and learning activities.

2) Programmatic / extracurricular activities are activities programmed by the campus to provide knowledge and skills in various fields that can accommodate talents, interests and other pedagogical needs. Programmed activities include:

a) Mandatory activities which consist of:

(1) speeches and discussions,

(2) computer,

(3) laboratory practicum, and

(4) self-defense sports.

b) Activities

c) options consist of:

(1) general sports,

(2) arts,

(3) robotic

(4) ketarunaan organization 
3) Projected Activities are activities carried out in the project at specified times and momentum. These activities include:

(1) Camp Saturday Sunday (Persami),

(2) Environmental Care Community Training (LKPL),

(3) commemoration of national holidays,

(4) campus traditions,

(5) competitions,

(6) creativity exhibition,

(7) entrepreneurship, and

(8) guest lecture / National Figure Meeting (JTN).

4) Creative Mandiri is an activity that is carried out independently by cadets outside of the above activities. Activities that include:

a) utilization of free time,

b) visits to the civil service's house, and

c) independent exercise.

Character education at the Jayapura Aviation Polytechnic is carried out in the form of activities. The activities that have been designed by the campus consist of scheduled, programmed, projected, and independent creative routines. The character education model in the form of activity eyes is by the opinion expressed by Suparno (2002: 42-44), namely the cultivation of character values can also be implanted through the eyes of activities outside formal learning activities. This model prioritizes the processing and cultivation of value through an activity to then discuss its life values.

The strategy used by the campus in implementing character education is through mental engineering and social engineering. Mental engineering is the internalization of the values of the nation's character and culture. Mental engineering is expected to manipulate a cadet's understanding mentally and intellectually. The purpose of mental engineering is the same as the opinion expressed by Khan (2010: 11) that the selfesteem approach is a strategy in the implementation of character education that aims to develop attitudes and awareness towards the humanization process. Social engineering is an implementation of mental engineering. The implementation of values is carried out through everyday life, socially through living together in one community with various rules that cadets must obey, and there are also procedures in life. Through mental and social engineering, these values will be internalized and become part of him. The strategy in implementing character education at Jayapura Aviation Polytechnic is in line with the opinion expressed by Megawangi (2004: 11) that character building starts from the stage of knowledge, understanding, implementation, to becoming a habit. Character is not only limited to knowledge but reaches deeper into the emotional aspect of self-habituation. Jayapura Aviation Polytechnic uses four kinds of approaches in the implementation of character education, namely intellectual, actual, inspirational, and exemplary approaches. The intellectual approach is carried out through teaching which contains efforts to cultivate values to provide the cognitive understanding and affective appreciation to cadets. This is by the opinion expressed by Hidayatullah (2010: 43) that character education requires a process of internalizing character values. The actual approach will actualize the value system that has become part of the cadets through various activities provided to the cadets with nurture and training. Through this actual approach, cadets will familiarize themselves with developing attitudes and behaviors in life by the values they have understood and experienced. This is by the opinion expressed by Hidayatullah (2010: 44), which is one approach in character education through habituation. Habit is directed at efforts to cultivate certain activities so that they become patterned and systemized activities. An inspirational approach is an effort to internalize values by creating situations and activities that can provide inspiring leadership for students.

The exemplary approach is an effort to internalize values by bringing the cadets together with society and their environment. 
In principle, the environmental tendency is created to be able to force strong and also prevent bad things related to the cadets' temperament from appearing, so it is hoped that creating a conducive environment will bring out positive attitudes and behaviors. This is by the opinion expressed by Hidayatullah (2010: 47) that the environment can be said to be a process of cultivating children which can be influenced by the conditions that children face and experience at any time. Creating a conducive atmosphere on campus is an effort to build a culture or culture that makes it possible to build character.

\section{CONCLUSION}

Character education at the Jayapura Aviation Polytechnic is applied in the form of activities. In its implementation, character education uses all of daily life as part of the education system that is being run. The strategy used in the delivery of character education is mental engineering and social engineering for the educational environment where cadets are located. The educational environment includes the social environment, namely life in dormitories and classrooms, educational relations with the tutors, administrative officials, and the surrounding community as well as guests or parents of students.

The natural environment, namely educational facilities, and infrastructure, including the garden environment. The internalization of certain value systems into cadets and their actualization in daily behavior attitudes is carried out through four kinds of approaches, namely the intellectual approach, the actual approach, the exemplary approach, and the inspirational approach.

The obstacles faced are divided into two, namely internal obstacles and external obstacles. The obstacles that arise from internal factors include the adaptation of cadets in the life of the boarding school at Jayapura Aviation Polytechnic, in addition to that the difficulty of the campus is the implementation of control over the development of cadets which is not proportional to the number of existing teachers. Meanwhile, the obstacles that arise from external factors are the occurrence of cultural infiltration and the surrounding community.

Efforts made to overcome obstacles include implementing an orientation period for the introduction of new cadets which aims to overcome the difficulties of adapting cadets to campus life. Also, sociometric controls were also carried out. Facing cadets who violate campus rules is not very persuasive, and also conditions the people around the Jayapura Aviation Polytechnic campus.

\section{Acknowledgement: None}

\section{Conflict of Interest: None}

\section{Source of Funding: None}

\section{REFERENCES}

1. Barnawi, dan M.Arifin, Strategi \& Kebijakan Pembelajaran Pendidikan Karakter,Jogjakarta: Ar-Ruzz Media, 2014.

2. Farida, Anna, Pilar-pilar Pembangunan Karakter Remaja: Metode Pembelajaran Aplikatif untuk Guru Sekolah Menengah, Bandung: Nuansa Cendikia, 2014.

3. Ichsan, "Menata Kembali Pendidikan Karakter di Sekolah", Jurnal Al-Bidayah, Vol. 3, Nomor. 2, Desember 2011.

4. Nurfalah, Yasin, "Urgensi Nilai-Nilai Pendidikan Karakter", Jurnal IAIT, Vol. 27, Nomor. 1, Januari 2016.

5. Pedoman Pola Pengasuhan Taruna, Kementerian Perhubungan RI Badan Pengembangan SDM Perhubungan, Jakarta, 2018.

6. Wardoyo, Sigit Mangun, "Pendidikan Karakter: Membangun Jati Diri Bangsa Menuju Genarasi Emas 2045 Yang Religius", Jurnal Tadris, Vol. 10, Nomor. 1, Juni 2015.

7. Milles, Matthew B dan A. Michael Huberman. 2007. Analisis Data Kualitatif.

8. Jakarta: Penerbit Universitas Indonesia.

9. Moleong, Lexy J. 1998. Metodologi Penelitian Kualitatif. Bandung: PT Remaja Rosadakarya. 
Jemi V. Palpialy et.al. The effectiveness and efficiency of cadets (student) care patterns implementation of character education in polytechnic flight Jayapura.

10. Moleong, Lexy J. 2004. Metodologi Penelitian Kualitatif. Bandung: PT Remaja Rosadakarya.

11. Munir, Abdullah. 2010. Pendidikan Karakter. Yogyakarta: PT Pustaka Insan Madani.

12. Mulyadi, Seto. 2008. Tinjauan Berbagai Aspek Character Building. Yogyakarta: Tiara Wacana.

13. Munib, Achmad. 2007. Pengantar Ilmu Pendidikan. Semarang: UPT UNNES Press.

14. Nazir, Moh. 2005. Metode Penelitian. Bogor: Ghalia Indonesia.

15. Qayyim AL-Jauziyah, Ibnu. 2005. Madarijus Salikin. Terjemahan Kathur Suhardi. Jakarta: Pustaka Al-Kautsar.

16. Rachman, Maman. 1999. Strategi dan Langkah-langkah Penelitian. Semarang: UNNES Press.

17. Rachman, Maman dan Muhsin. 1996. Konsep dan Analisis Statistik. Semarang: UNNES Press.

18. Sugandi, Achmad.2007. Teori Pembelajaran. Semarang: UPT UNNES Press.

19. Suhartono, Suparlan. 2007. Filsafat Pendidikan. Yogyakarta: AR-Ruzz Media.
Sulham, Najib. 2010. Pendidikan Berbasis Karakter. Surabaya: PT Jepe Press

20. Media Utama.

21. Suparno. Pendidikan Karakter. (pendidikan-karakter/konselorIndonesia.html).

22. Suratno, Pardi. 2006. Sang Pemimpin: Menurut Asthabrata, Wulang Reh, Tripama, dan Dasa Darma Raja. Yogyakarta: Adi Wacana.

23. Suwarno, Wiji. 2006. Dasar - Dasar Ilmu Pendidikan. Yogyakarta: AR-Ruzz Media.

24. UU No. 20 Tahun 2003 Tentang Sistem Pendidikan Nasional.

25. Zuriah, Nurul. 2008. Pendidikan Moral dan Budi Pekerti Dalam Perspektif Perubahan. Jakarta: Bumi Aksara.

How to cite this article: Palpialy JV, Makanuay A. The effectiveness and efficiency of cadets (student) care patterns implementation of character education in polytechnic flight Jayapura. International Journal of Research and Review. 2021; 8(4): 316-325. DOI: https://doi.org/10.52403/ijrr.20210438 